\title{
Effects of Tillage System and Soil Organic Matter Amendment on Growth, Yield of Pathumthani 80 Rice and Carbon Sequestration in Paddy Soil
}

\author{
Kanyarat Buarach ${ }^{1}$, Chaisit Thongjoo ${ }^{1}$, Nawarat Udomprasert ${ }^{2} \&$ Suphachai Amkha $^{1}$ \\ ${ }^{1}$ Department of Soil Science, Faculty of Agriculture at KamphaengSaen, Kasetsart University, KamphaengSaen \\ Campus, Nakhonpatom 73140, Thailand \\ ${ }^{2}$ Department of Agronomy, Faculty of Agriculture at KamphaengSaen, Kasetsart University, KamphaengSaen \\ Campus, Nakhonpatom 73140, Thailand \\ Correspondence: Suphachai Amkha, Department of Soil Science, Faculty of Agriculture at KamphaengSaen, \\ Kasetsart University, KamphaengSaen Campus, Nakhonpatom 73140, Thailand. E-mail: agrscak@ku.ac.th
}

Received: February 20, 2014 Accepted: April 15, 2014 Online Published: June 25, 2014

doi:10.5539/mas.v8n4p1

URL: http://dx.doi.org/10.5539/mas.v8n4p1

\begin{abstract}
This study was conducted to determine the effect of tillage systems and soil organic amendments on rice growth, yield and carbon sequestration on paddy soil. The experiment was conducted by using $2 \times 4$ factorials in complete randomized design. The first factor was tillage systems (conventional tillage; to and minimum tillage; $\mathrm{t} 1$ ) and the second factor was soil organic amendments (mungbean; $\mathrm{p} 0$, sesbania; $\mathrm{p} 1$, sunhemp; $\mathrm{p} 2$ and rice straw; $\mathrm{p} 3$ ). The results demonstrated that adding organic matter derived from mungbean to the soil was the highest and significantly different of plant height and carbon stock in rice $(\mathrm{P} \leq 0.01)$. The tillage system and organic matter amendment was not significantly different of rice yield. However, tillage systems with a mungbean amendment tent to increased the rice yield. Soil organic matter was the highest in sumhep amendment in soil as following by sesbania, mungbean and rice straw, respectively. In addition, minimum tillage system can increase carbon sequestration in soil at $15 \mathrm{~cm}$ soil depth $(\mathrm{P} \leq 0.01)$.
\end{abstract}

Keywords: rice, tillage, soil organic carbon, soil carbon sequestration

\section{Introduction}

Rice is an important industrial crop of Thailand and a major staple food for the Thai people. Thai encompasses a rice-growing area of approximately 60 million ha, (25\%) produce irrigated rice (Office of Agricultural Economics, 2012). The average rice yield is approximately $452 \mathrm{ka} \mathrm{ha}^{-1}$, which is relatively low. Some factors that contribute to the low yield may include the grain quality, an unsuitable seed rate, and the use of chemical fertilizers and pesticides in inappropriate quantities. In addition, the selection of either conventional tillage or reduced tillage affects the physical and chemical soil properties. Yagi and Minami (1990) reported that the reduced-tillage system leaves crop residues on the soil surface that amount to approximately $48 \%$ of the conventional tillage system residues. The plants are beneficial to the organisms in the soil and increased the survival of soil-dwelling microorganisms. Additionally, reduced-tillage increases the amount of organic matter in the soil to a greater extent compared to traditional tillage, because tillage typically adds air into the soil, the microbes that use oxygen for respiration will decompose organic matter more quickly, thus decreasing the amount of the organic matter in the soil. Balesdent et al. (1990) reported the reduced tillage leaves crop residues on the soil surface and reduce the loss of soil organic matter. The soil layer under no-till or reduced-tillage was observed to harbor increased amounts of organic matter and carbon compared with conventionally tilled soil. Moreover, the report revealed that adding green manure, which is produced by chopping or plowing, as an organic fertilizer while the plant is still green (during the flowering period) results in the release and decomposition of the plant, which increases the amount of nutrients and organic matter in the soil. Legumes are a commonly type of green manure because they are easily manipulable crop and grow well. The Rhizobium bacteria (Rhizobium sp.) that reside in the Rhizosphere legumes help in nitrogen compounds which are utilized by plants. 
Contemporary data indicate that agriculture sector activity emits approximately 6,615 million tons of carbon dioxide, which represents $13.5 \%$ of the total greenhouse gas emissions. Deforestation that changes the crop area yields the most emissions: approximately 5,900 million tons of carbon dioxide, or approximately $47.1 \%$ of all emission from the agriculture sector. The chemical-mediated release of carbon dioxide from the soil, methane emissions from livestock, incineration and paddy cultivation account for $16.9 \%, 14.3 \%, 5.4 \%$ and $4.9 \%$, respectively, of carbon emission. Soil is a large carbon sink that reduces and retards global warming. The storage of carbon in soil is termed soil organic carbon. The increase of organic carbon in soil depends on soil management schemes, such as the addition of organic fertilizer, organic manure and green manure. Long-term carbon storage will result in a reduction of carbon dioxide emission by reducing the primary gases that potentiate the greenhouse effect. Duiker et al. (2003) has demonstrated that soil is an important source for carbon storage. The distribution of carbon is approximately 6,211,706 million tons, which is equivalent to $6.21 \mathrm{Pg}$ or $0.046 \%$ of the organic carbon in the world. Thus, rice growing areas harbor the potential to become a source for carbon storage. This study aimed to investigate the effects of reduced tillage and organic matter added to soil where rice is planted on rice growth and the accumulation of carbon in the soil. These experiments aimed to investigate the effects of reduced tillage together with organic matter use in soil planted with rice on rice growth and the accumulation of carbon in the soil.

\section{Methods}

We chose paddy plots where Pathumthani 80 rice is grown in the Wang-Wha district, Sriprajan, Suphanburi province. These plots contain Saraburi soil series, which exhibits certain chemical and physical properties, such as a dark gray and brown clay texture, strongly acidic soil, relatively low amounts of organic matter, a lack of beneficial phosphorus, a high-potassium exchange, and a bulk density of $1.0 \mathrm{~g} \mathrm{~cm}^{-3}$. The experiment was initiated by preparing $5 \times 5 \mathrm{~m}$ planting plots and 32 plots, followed by the preparation of pathumtani 80 rice seedlings from 20-day-old seedling, which were transplanted at a spacing of $20 \times 20 \mathrm{~cm}$. This study used a $2 \times 4$ factorial to completely randomize the two-factor design. Conventional tillage ( $\mathrm{t} 0)$ and minimum tillage (t1) comprised the first factor. The second factor comprised four types of organic matter: mung bean ( 00 ), Sesbania (p1), sunnhemp (p2) and rice straw (p3), which were planted in paddy plots and then plowed during the flowering, stage (Schomberg et al., 2007). Then, each plot was left untouched for one month so that fresh residue could decompose before rice was planted. This procedure was replicated for four experiments. The fertilization was divided into two time sequences. The first fertilization used 16-20-0 at $25 \mathrm{~kg} \mathrm{ha}^{-1}$ after 7-10 days from the rice transplantation dates. The second fertilization used 46-0-0 at $10 \mathrm{~kg} \mathrm{ha}^{-1}$ after $45-50$ days. The collected growth data included the plant height and tiller number at 84 days after transplanting. The grain yield data were collected by using the grain weight per square meter to determine yield weight. Soil samples were collected before and after planting to analyze the soil bulk density and some soil properties. We used a CN Analyzer to assess the amount of organic matter and the carbon content in the soil (Tasanee \& Chongrak, 1999). The amount of carbon accumulation was calculated by multiplying the carbon content, bulk density and soil depth (Tilak \& Ranganayaki, 2006). We analyzed the crop samples after their harvest by drying the plant samples at $70{ }^{\circ} \mathrm{C}$ for three days and then collecting and grinding the dry weight to determine the total carbon using the CN Analyzer. Next, we calculated the carbon storage the carbon storage of the plants by multiplying the dry weight and the concentration of carbon of carbon calculated from the analysis (Wasant et al., 2010).

\section{Results and Discussion}

Effects of the tillage system in combination with organic matter supplementation on rice growth

\subsection{Plant Height}

The result of the research when the growing of the rice from the different type management found that tillage system with organic matter supplement in the soil was not significantly different growing of the rice (Table 1). However, the minimum-tillage or conventional tillage system together with mung bean supplement in the soil was tent to increased of the plant height because of the rhizobium bacteria (Rhizobium sp.) at the rhizosphere of the mung bean that can be promote the fixation of nitrogen into amino acid and nitrogen compounds that are beneficial for the plant and for soil fertility (Claudine et al., 2009). The amount of nitrogen fixation of rhizobium in mung bean is $60-340 \mathrm{~kg} \mathrm{~N}^{-1}$ (Jana \& Richard, 2002). Then mung bean can help to produce more the nitrogen and accumulate nitrogen in the stem and root, and released nitrogen after plowing more than seabania, sunhemp and rice straw that enhanced the plant height of rice. 
Table 1. Effects of tillage system and organic matter amendment on plant height at 84 days after transplanting (DAT)

\begin{tabular}{lccc}
\hline \multicolumn{1}{c}{ Treatment } & Conventional (t0) & Minimum-tillage (t1) & Average (p) \\
\hline Mung Bean (p0) & 140 & 140 & $140 \mathrm{a}$ \\
Sesbania (p2) & 128 & 130 & $129 \mathrm{~b}$ \\
Sunhemp (p1) & 134 & 134 & $134 \mathrm{~b}$ \\
Rice Straw (p3) & 135 & 129 & $132 \mathrm{~b}$ \\
\hline Average (t) & 134 & 133 & \\
\hline C.V. (\%) & & 5.12 & \\
\hline
\end{tabular}

Note. Number is average of 4 replications, followed by a letter. Different letter means there is a significant different at $99 \%$ by Duncan method.

\subsection{Tiller Number}

The tillers number was non significantly different between the conventional tillage and minimum-tillage conditions with organic matter supplementation (Table 2). However, minimum-tillage in combination with sunhemp was tent to increased the till number of rice. The reduce tillage can be to enhanced soil organic matter and increased cation exchangeable capacity in soil that cause to change the nutrient unviable form to available form (Haynes, 2005). Moreover, adding organic matter derived from sunhemp caused the largest amount of tiller number of rice because the decomposition of sunhemp the flowering stage can produce acid, which promotes the dissolution of nutrient in the soil and sometime can control the life cycle of insect and weed (Graham et al., 2002). Sunhemp is a type of legume that can fix nitrogen the atmosphere and the release it as ammonia after degradation. This process can be utilized to produce healthy rice plants with adequate root depth, higher tiller, strong leaf blades, resistance to disease and insect and a reluctance to fall when the panicle emerges. Therefore, using minimum-tillage together with sunhemp-derived organic matter supplementation can result in high-tillering rice. (Kerek et al., 2002) has been used effectively to reflect the biomass component of active soil organic matter (SOM).

Table 2. Effects of tillage system and organic matter amendment on tiller number at 84 DAT

\begin{tabular}{lccc}
\hline \multicolumn{1}{c}{ Treatment } & Conventional (t0) & Minimum-tillage (t1) & Average (p) \\
\hline Mung Bean (p0) & 11 & 12 & 12 \\
Sesbania (p2) & 10 & 9 & 9 \\
Sunhemp (p1) & 10 & 10 & 10 \\
Rice Straw(p3) & 9 & 10 & 9 \\
\hline Average (t) & 10 & 10 & \\
\hline C.V. (\%) & & 18.22 \\
\hline
\end{tabular}

Note. Non-significantly different at $95 \%$ by Duncan method.

\subsection{Effects of Using a Tillage System in Combination with Organic Matter Supplementation on Yield of Rice}

The difference of tillage system management was not significantly different in yield of pathumthani 80 rice at 84 DAT. On light-textured soils and in dry years, tillage yields have generally been greater than conventional-tillage yields. In fact for many years, continuous minimum-tillage on heavier clay soils was discouraged, although rotation of crops is known to reduce the adverse effects on crop yield sometimes associated with minimum-tillage on these soils (Conant et al., 2004). However, minimum-tillage more than to save the high yield, the different of tillage system management combination with organic matter supplement in soil did not significantly different in yield. However, recent results from long-term minimum-tillage studies in Ohio on heavy soils, which remain wetter and cooler in the spring, have indicated that minimum-tillage crop yields on these soils have been equal to or better than conventional-tillage yields (Monzon et al., 2006). Nevertheless, sound crop rotations are often the foundation of a profitable cropping system. There are some initial costs for implementing crop rotations, such as 
extra equipment, but in the final analysis these costs may be more than overcome by the reduced inputs, timeliness, and higher yields (Gan, 2009).

Table 3. Effects of tillage system and organic matter amendment on yield $\left(\tan \mathrm{ha}^{-1}\right)$

\begin{tabular}{lccc}
\hline \multicolumn{1}{c}{ Treatment } & Conventional (t0) & Minimum-tillage (t1) & Average (p) \\
\hline Mung Bean (p0) & 10.05 & 8.38 & 9.21 \\
Sesbania (p1) & 5.98 & 8.65 & 7.31 \\
Sunhemp (p2) & 8.77 & 9.40 & 9.08 \\
Rice Straw (p3) & 8.75 & 9.13 & 8.93 \\
\hline Average (t) & 8.39 & 8.89 & \\
\hline C.V. $(\%)$ & & 18.19 & \\
\hline
\end{tabular}

Note. Non-significantly different at $95 \%$ by Duncan method.

\subsection{Effects of Using a Tillage System in Combination with Supplemented Organic Matter on the amount of Organic} Matter in the Soil

The difference of tillage system management was not significantly difference in soil organic matter. However, the difference of organic matter supplement in soil was significantly different in soil organic matter. Because soils have lost so much $\mathrm{C}$ since tillage began, the idea that a reduction in tillage would sequester $\mathrm{C}$ seems plausible (Polyakov, 2008). However, other changes beyond mechanical disturbance of the soil that may have had far more impact on SOC. Perhaps the most obvious difference between today's agricultural lands and the ecosystems that preceded them is that agriculture is dominated by annual crops (Sauer et al., 2007). One of the most pronounced effects of conservation tillage, especially minimum-tillage, is the accumulation of residues and organic matter on the soil surface. Not only is there a redistribution or stratification within the soil profile, but several studies have clearly shown that conservation-tillage maintains higher total amounts of organic matter in the soil profile than do the more intensively tilled systems (Yoneyama et al., 2006). In addition, sunhemp supplement application in soil found that soil organic matter was higher than sesbania, mungbean and rice straw, respectively. While, the difference of tillage system management combination with organic matter supplement in soil at 84 days after transplanting (DAT) is not significantly different SOM.

Table 4. Effects of tillage system and organic matter amendment on organic matter (\%)

\begin{tabular}{lccc}
\hline \multicolumn{1}{c}{ Treatment } & Conventional (t0) & Minimum-tillage (t1) & Average (p) \\
\hline Mung Bean (p0) & 3.97 & 4.13 & $4.05 \mathrm{a}$ \\
Sesbania (p1) & 4.27 & 4.19 & $4.23 \mathrm{a}$ \\
Sunhemp (p2) & 4.28 & 4.35 & $4.32 \mathrm{a}$ \\
Rice Straw (p3) & 2.94 & 2.79 & $2.87 \mathrm{~b}$ \\
\hline Average (t) & 3.67 & 3.87 & \\
\hline C.V. (\%) & & 14.19
\end{tabular}

Note. Number is average of 4 replications, followed by a letter. Different letter means there is a significant different at $99 \%$ by Duncan method.

\subsection{Effects of the Tillage System and Adding Organic Matter on the Carbon Stock in Soil (Mg ha $\left.{ }^{-1}\right)$}

The difference of tillage system management was significantly different carbon stock in soil while, minimum-tillage can sequestration carbon in soil more than conventional tillage. Observed that reducing tillage data indicate that minimal residue incorporation into soil with conservation tillage induced soil organic carbon (SOC) stratification, the mixing of crop residues with disk tillage resulted in little change between initial and final SOC contents in either depth. Dolan et al., (2006) was support the generally accepted view that widespread adoption of conservation tillage, and specifically minimum-tillage, would sequester a substantial amount of 
carbon because, nitrification and denitrification are also important $\mathrm{N}$ processes affected by tillage. Nitrification is reduced under acid conditions which suggest that in soils where conservation tillage is practiced, nitrification would be lower than in tilled soils. In fact, several studies have reported that minimum-tillage soils contain less itrates and manure application and no-tillage cultivation on agricultural land are regarded as techniques for carbon sequestration through their ability to increase SOC (Shirato et al., 2005). However, the different of organic matter supplement in soil was not significantly different in carbon stock. In addition, mungbean supplement application in soil found that soil organic matter was higher than, sunhemp, sesbania and rice straw, respectively. While, the different of tillage system management combination with organic matter supplement in soil at 84 days after transplanting (DAT) was not significantly different carbon stock in soil. Moreover, adding mungbean-derived organic matter to the soil increased carbon sequestration in the soil more than adding organic matter derived from other plants, most likely due to the plowing of mungbean. Increased amounts of organic matter improve the physical properties of the soil, such as good soil aggregation, which results in an improved soil structure that allows plant roots to better absorb nutrients.

Table 5. Effects of tillage system and organic matter amendment on carbon stock in soil at 84 DAT $\left(\mathrm{Mg}^{-1}\right)$ at 15 $\mathrm{cm}$ soil depth

\begin{tabular}{lccc}
\hline \multicolumn{1}{c}{ Treatment } & Conventional (t0) & Minimum-tillage (t1) & Average (p) \\
\hline Mung Bean (p0) & 39.16 & 44.22 & 41.68 \\
Sesbania (p1) & 40.44 & 36.75 & 38.59 \\
Sunhemp (p2) & 35.80 & 40.33 & 39.89 \\
Rice Straw (p3) & 40.01 & 35.31 & 37.66 \\
\hline Average (t) & $38.85 \mathrm{~b}$ & $39.15 \mathrm{a}$ & \\
\hline C.V. (\%) & & 10.78 &
\end{tabular}

Note. Number is average of 4 replications, followed by a letter. Different letter means there is a significant different at $99 \%$ by Duncan method.

\subsection{Effects of the Tillage System with Adding Organic Matter on the Carbon Stock in Rice $\left(\mathrm{kg} \mathrm{ha}^{-1}\right)$}

The difference of tillage system management was non significantly different carbon stock in rice but, minimum-tillage can sequestration carbon in soil more than conventional tillage. However, the difference of organic matter supplement in soil was significantly different carbon stock in rice. In addition, mungbean supplement application in soil found that soil organic matter was higher than sunhemp, rice straw and sesbania, respectively. $\mathrm{N}_{2} \mathrm{O}$ emissions from crop residues applied to soil were highest from leaf and stem, mungbean. $\mathrm{N}_{2} \mathrm{O}$ emission was higher in plots treated with residues with a low $\mathrm{C}: \mathrm{N}$ ratio, possibly because residues with a low $\mathrm{C}: \mathrm{N}$ ratio are more easily decomposed. There was a negative logarithmic relationship between and residue $\mathrm{C}: \mathrm{N}$ ratio (Huang \& Zou, 2004). Many rangelands are N-limited, so increasing $\mathrm{N}$ inputs by inteeerseeding $\mathrm{N}$-fixng legumes can increase forage production and quality as well as carbon sequestration (Bavin et al., 2009). The introduction of $\mathrm{N}$-fixing legumes as an alternative to $\mathrm{N}$-fertilization has been the subject of research for decades compared two adjacent fields, both in maize/soybean rotation, with one under conventional tillage and the other under strip tillage, a conservation tillage practice in which most of the surface is undisturbed. They found no $\mathrm{C}$ sequestration benefit from the conservation tillage, and both systems were apparently small net sources of $\mathrm{C}$ over the 2-year period (Verma et al., 2005). Tillage impacts can be investigated by studying both the total microbial biomass and individual components of the biomass. The microbial biomass acts as the transformation agent of the organic matter in soil and represents both a sink and source of nutrients. At first glance, much of the data reported would suggest that the microbial biomass fraction seems to be less efficient in a conservation-tillage soil than in a tilled soil, i.e. organic matter accumulates under no tillage even though the biomass is larger and seemingly core active. While, the difference of tillage system management combination with organic matter supplement in soil at 84 days after transplanting (DAT) did not significantly different SOM. 
Table 6. Effects of tillage system and organic matter amendments on carbon stock in rice at 84 DAT $\left(\mathrm{kg} \mathrm{ha}^{-1}\right)$

\begin{tabular}{lccc}
\hline \multicolumn{1}{c}{ Treatment } & Conventional (t0) & Minimum-tillage (t1) & Average (p) \\
\hline Mung Bean (p0) & 526.25 & 586.75 & $556.5 \mathrm{a}^{1 /}$ \\
Sesbania (p1) & 490.52 & 405.87 & $448.18 \mathrm{~d}$ \\
Sunhemp (p2) & 514.68 & 530.93 & $522.81 \mathrm{~b}$ \\
Rice Straw (p3) & 488.8 & 508.68 & $498.87 \mathrm{c}$ \\
\hline Average (t) & 505.12 & 508.00 & \\
\hline C.V. (\%) & & 8.61 &
\end{tabular}

Note. Number is average of 4 replications, followed by a letter. Different letter means there is a significant different at $99 \%$ by Duncan method.

\section{Conclusion}

In conclusion, adding organic matter with mung bean tends to give the good of plant height, tiller number and yield. In addition, increasing the amount of organic matter in the soil with sunhepm found the highest amounts of SOM follow by adding sesbania, rice straw, and mung bean, respectively. For the carbon sequestration found that the reduced tillage with mung bean increased carbon stock in soil and plant.

\section{Acknowledgement}

This paper was supported by gradute research fund for publication in international academic journals. We are grateful for the financil support by Graduate School of Kasetsart University, Thailand. Also, our thanks Assoc. Prof. Dr. Thongchai Mala for valuable suggestions.

\section{References}

Balesdent, J., Mariotti, A., \& Boisgontie, D. (1990). Effect of tillage on soil carbon mineralization estimated from C abundance in maize fields. J. Soil Sci., 41, 587-596. http://dx.doi.org/10.1111/j.1365-2389.1990.tb00228.x

Conant, R. T., Dalla-Betta., P., Klopatek, C. C., \& Klopatek, J. M. (2004). Controls on soil respiration in semiarid soils. Soil Biol. Biochem., 36, 945-951. http://dx.doi.org/10.1016/j.soilbio.2004.02.013

Duiker, S. W., Rhoton, F. E., Torrent, J. Smeck, N. E., \& Lal, R. (2003). Iron (hydra) oxide crystalline effects on soil aggregation. Soil Sci. Soc. Am. J., 67, 606-611. http://dx.doi.org/10.2136/sssaj2003.6060

Franzluebbers, A. J. (2008). Linking soil and water quality in conservation agricultural system. J. Integr. Biosci, 6, 15-29.

Gan, Y. T., Campbell, C. A., Janzen, H. H., Lemke, R. L., Basnya,T. P., \& McDonald, C. L. (2009). Carbon input to soil from oilseed and pulse crops on the Canadian prairies. Agri. Ecosyst. Environ, 132, 290-297. http://dx.doi.org/10.1016/j.agee.2009.04.014

Graham, M. H., Haynes, R. F., \& Meye, J. H. (2002). Soil organic matter content and quality: effects of fertilizer applications, burning and trash retention on a long-term sugarcane experiment in South Africa. Africa. Soil Biol. Biochem., 34, 93-102. http://dx.doi.org/10.1016/S0038-0717(01)00160-2

Haynes, R. J. (2005). Labile Organic Matter Fractions as Central Components of the Quality of Agricultural Soils. J. Advances in Agronomy, 85, 221-268. http://dx.doi.org/10.1016/S0065-2113(04)85005-3

Huang, Y., Zou, J., Zheng, X., Wang, Y., \& Xu X. (2004). Nitrous oxide emissions as influenced by amendment of plant residues with different C:N ratio. Soil Biol. Biochem., 36, 973-981. http://dx.doi.org/10.1016/j.soilbio.2004.02.009

Jana, E., Richard C., \& Boone D. (2002). Soil nitrogen transformations and the role of light fraction organic matter in forest soils. J. Soil Bio. Biochem, 34, 933-943. http://dx.doi.org/10.1016/S0038-0717(02)00025-1

Kerek, M., Drijber, R. A., Powers, M. J., Shearman, R. C., Gaussoin, R. E., \& Streich, A. M. (2002). Accumulation of microbial biomass within particulate organic matter of aging golf greens. Agron. J. 94, 455-461. http://dx.doi.org/10.2134/agronj2002.0455

Lal R. (2003). Global potential of soil carbon sequestration to mitigate the greenhouse effect. Crit. Rev. Plant Sci., 22, 151-184. http://dx.doi.org/10.1080/713610854 
Lasco, R. D., Ogle, S., \& Raison, J. (2006). Cropland. In Agriculture, Forestry and Other Land Use, 2006 IPCC Guidelines for National Greenhouse Gas Inventories, 5, 1-5. Institute for Global Environmental Strategies, Hayama.

Monzon, J. P., Sadras V. O., \& Andrade F. H. (2006). Fallow soil evaporation and water storage as affected by stubble in sub-humid (Argentina) and semi-arid (Australia) environments. Field Crops Research, 98, 83-90. http://dx.doi.org/10.1016/j.fcr.2005.12.010

Polyakov, V. O., \& Lal R., (2008). Soil organic matter and $\mathrm{CO}_{2}$ emission as affected by water erosion on filed runoff plots. Geoderma, 143, 216-222. http://dx.doi.org/10.1016/j.geoderma.2007.11.005

Sauer, T. J., Cambardella, C. A., \& Brandle, J. R. (2007). Soil carbon and tree litter dynamics in a red cedar-scotch pine shelterbelt. Agrofor. Syst, 71, 163-174. http://dx.doi.org/10.1007/s10457-007-9072-7

Schomberg, H. H., Martini N. L., Diaz-Perez J. C., Phatak S. C., Balkcom K. S., \& Bhardwaj H. L. (2007). Potential for using sunn hemp as a source of biomass and nitrogen for the Piedmont and Coastal Plain regions of the southeastern USA. Agronomy Journal, 99, 1448-1457. http://dx.doi.org/10.2134/agronj2006.0294

Shirato, Y., Paisancharoen, K., Sangtong, P., Nakviro, C., Yokozawa, M., \& Matsumoto, N. (2005). Testing the Rothamsted Carbon Model against data from long-term experiments on upland soils in Thailand. Eur. J. Soil Sci., 56, 179-188. http://dx.doi.org/10.1111/j.1365-2389.2004.00659.x

Yagi. K., \& Minam, I M. (1990). Effect of organic matter application on methane emission from some Japanese paddy fields. Soil Sci. Plant Nutr, 36, 599-610. http://dx.doi.org/10.1080/00380768.1990.10416797

Yoneyama, T., Okada H., Chongpraditnum, P., Ando, S., Prasertsak, P., \& Hirai, K. (2006). Effects of vegetation and cultivation on $13 \mathrm{C}$ values of soil organic carbon and estimation of its turnover in Asian tropics: A case study in Thailand. J. Soil Sci. Plant Nutr., 52, 95-102. http://dx.doi.org/10.1111/j.1747-0765.2006.00001.x

\section{Copyrights}

Copyright for this article is retained by the author(s), with first publication rights granted to the journal.

This is an open-access article distributed under the terms and conditions of the Creative Commons Attribution license (http://creativecommons.org/licenses/by/3.0/). 